\title{
GENETIC EFFECT OF MAGNETIC FIELD ON GROWTH AND PROTEIN CONTENTS OF MAIZE, BEAN AND Bacillus sp IN VITRO. \\ Haggran, A.A. ${ }^{1}$; M.H. Abou-Deif ${ }^{2}$ and Sh. Sharaf El-Deen ${ }^{1}$ \\ 1- Microbial Genetics Dept. National Res. Centre, Dokki, Cairo, Egypt. \\ 2- Genetics and Cytology Dept. National Res. Centre, Dokki, Cairo, Egypt.
}

\begin{abstract}
Physical mutagenesis as radiation, electrical field, magnetic field...etc., were inspired to enhance or modify their biological behavior. This work was carried out to detect the change in some properties and chemical constituents of maize (variety S.C.10) and bean (variety Nebraseca ) seeds after exposure to magnetic field such as root weight and length, shoot height, proteins, amino acids and protein banding pattern. The density flux of magnetic field was 0.5 Tesla and exposure times were 15 and $30 \mathrm{~min}$. Seeds were placed at suitable distance between magnetic dipoles. Paper chromatography detected increase in some amino acids as aspartic acid, glutamic acid, and methionine in both maize and bean seeds after exposure to magnetic field. The total protein of maize seedlings decreased by $66 \%$ after $30 \mathrm{~min}$ of exposure to magnetic field. Protein pattern detected new bands after 30 min of magnetic field exposure in maize and bean. The germination and growth of maize and bean seeds were affected after magnetic field exposure. Root weight of maize was decreased $66 \%$ but in bean the decrease of root weight was not significant. The maize shoots were increased $66 \%$ and $233 \%$ after magnetic field exposure for 15 and $30 \mathrm{~min}$, respectively. The bean shoots increased $27.3 \%$ and $63.6 \%$ after magnetic field exposure for 15 and $30 \mathrm{~min}$, respectively. The results indicated that the magnetic field can produce plants free of Bacillus sp, increases some amino acids contents and also increases maize and bean shoots growth.

Keywords: Maize, Bean, Magnetic field, Bacillus sp, Protein pattern.
\end{abstract}

\section{INTRODUCTION}

Chemical and physical mutagens were used widely for producing mutations and/or increasing genetic variability in target materials. It is well known that mutagens could directly induce physiological changes, point mutations and chromosomal aberrations. Magnetic field (MF) can also be used for the same purpose due to their biological effects (Mastude et al., 1993). There are a lot of biological effects include carcinogenesis that has been attributed to MF, but there is no clear data about the mutagenic effect of MF (Schreiber et al., 2001; Novikov et al., 2002). The evaluation of MF effects on the biological systems is difficult, since most of the biological structures are heterogeneous (Goodman et al., 1995).

The previous studies indicated that the MF affects on plant growth and germinations, and that frequency of the field is an important factor on germination rates. Maximum germination rates $(20 \%$ increasing in the treatment higher than the control) were obtained at around $10 \mathrm{~Hz}$. The MF of $10 \mathrm{~Hz}$ also produced a statistically significant effect on plant growth, as measured by leaf area. The difference in growth rate between treated and control plants decreased after the field was removed (Namba et al., 1995). 
Haggran, A.A. et al.

The application of high magnetic fields (1 Tesla and above) produced marked effects on germination and growth of plants, especially corn and peas (Chen, 1999). Recently Novak et al. (2007) found that the MF decreases the number of yeasts, and also down their growth, which it seems that the MF kills a part of yeasts. They reported that this result was similar to the experiments with bacteria $E$. coli, S. aureus and $L$. adecarboxylata.

Certain types of stressful environmental conditions can activate stress genes to produce stress proteins that enable organisms to tolerate such stresses. Biochemical markers have been used to distinguish between homozygous and heterozygous individuals and to estimate the level of genetic variability in plant populations (Mulchinger et al 1992). Hussien and Stegemann (1978) reported that sodium dodecyl sulphate-polyacrylamide gel electrophoresis (SDS-PAGE) of total grain proteins was a rapid method to screen varietal differences.

This work aimed to estimate the effect of magnetic field on germination and growth of maize, bean and Bacillus sp in Vitro. Chemical constituents of protein and amino acids contents and protein banding pattern were also evaluated.

\section{MATERIALS AND METHODS}

\section{Plant materials}

Seeds of "Nebrasca" bean variety (Phaseolus vulgaris L.) and grains of "Single Cross 10" maize variety (Zea mays L.) were kindly supplied from Agriculture Research Center, Giza, Egypt. MS medium (Murashige and Skoog, 1962) was used in maize and bean seeds cultures. Nutrient broth medium, consists of $0.8 \%$ nutrient broth and distilled water, was used to grow Bucillus sp. wild type strain.

\section{Magnetic field}

The seeds were exposed to MF (Newport Pangell Instrument, Oxford, UK). The MF applied was $10 \mathrm{~kg}$ at 0.5 Tesla as field strength or density flux $(\mathrm{H})$ with a current of 0.25 Amps. After MF exposure for two times $15 \mathrm{~min}$ and $30 \mathrm{~min}$, seeds were sterilized in $5.25 \%$ sodium hypochlorite for 15 min and washed many times with sterile distilled water, blotted and planted on MS medium and incubated at $23^{\circ} \mathrm{C}$ in light for 10 days.

\section{Amino acids and protein determination}

Amino acids were estimated using paper chromatography and Ninhydrin solution for displaying method (Cassidy, 1957). Protein extraction was carried out according to Bollage and Edelstein (1992). Total protein concentration was estimated according to method of Brandford (1976).

\section{Protein electrophoresis}

Samples of $1 \mathrm{~g}$ kernel flour from each of the maize and bean seed varieties, that exposed to the MF and unexposed seeds as controls, were used for protein electrophoretic analysis. Sodium dodecyl sulfate polyacrylamide gel electrophoresis (SDS-PAGE) analysis was performed (Laemmli, 1970). The sample preparation and extraction of seed watersoluble proteins was performed (Stegemann et al 1980). Gel was photographed and scanned by Gel Doc Bio-Rad System (Gel - Pro analyzer V3). 


\section{RESULTS AND DISCUSSION}

\section{Seed germination and growth}

The seeds of maize and bean were exposed to MF for 15 and 30 min. The effect of treatments on root and shoot growth is shown in Figure (1) and Table (1). The root weight of maize and bean seedlings decreased with increasing the time of MF exposure comparing to the control. Similar results were obtained for root length after treatment with MF, which the length decreased comparing to the control after 15 and $30 \mathrm{~min}$ of exposure. In contrast, the shoot height increased after treatments with MF in both maize and bean plantlets. These results are in agreement with those of Chen (1999) who reported that the application of high magnetic fields (1 Tesla and above) produced marked effects on germination and growth of plants, especially corn and peas. Namba et al. (1995) found that maximum germination rates $(20 \%$ increasing in the treatment higher than the control) were obtained at around $10 \mathrm{~Hz}$. The MF of $10 \mathrm{~Hz}$ also produced a statistically significant effect on plant growth.

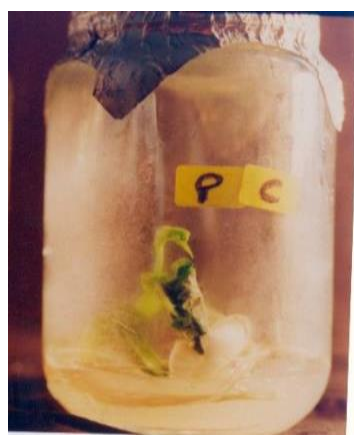

(1)

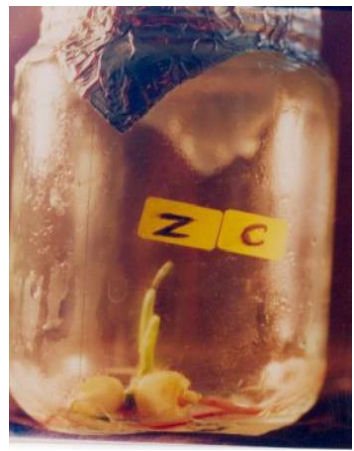

(4)

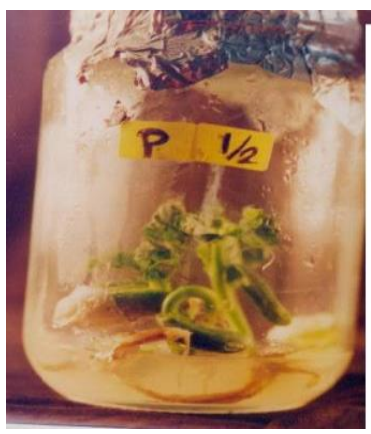

(2)

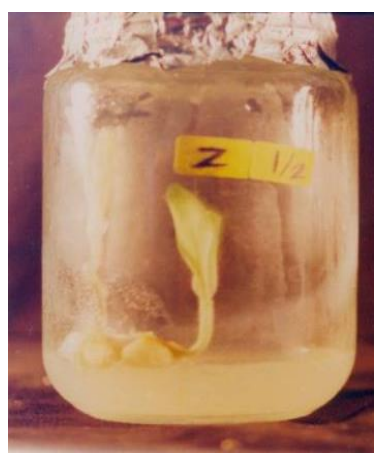

(5)

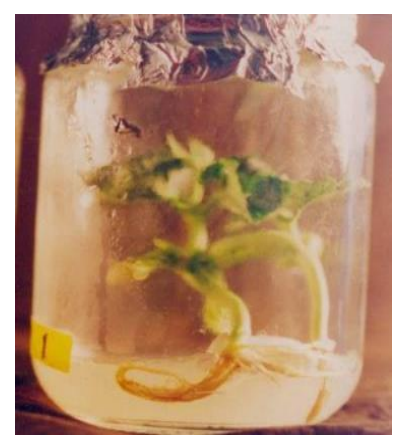

(3)

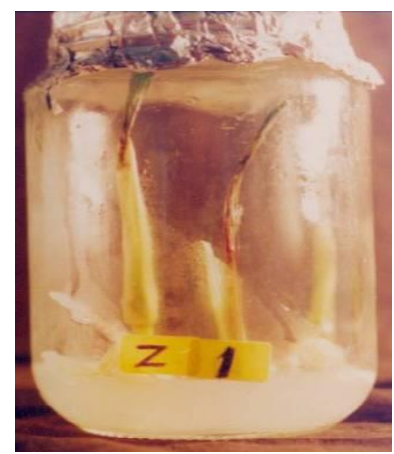

(6)

Fig. 1: Seedling growth on MS medium after 10 days of germination. Bean: (1) without MF exposure, (2) $15 \mathrm{~min}$ of MF exposure and (3) 30 min of MF exposure. Maize: (4) without MF exposure, (5) $15 \mathrm{~min}$ of MF exposure and (6) $30 \mathrm{~min}$ of MF exposure. 
Haggran, A.A. et al.

Table (1): Root length, weight and shoot height of maize and bean seedlings after 10 days of germination.

\begin{tabular}{|c|c|c|c|c|}
\hline Seeds & MF/time & $\begin{array}{c}\text { Root length } \\
\text { (cm) }\end{array}$ & $\begin{array}{c}\text { Root weight } \\
(\mathbf{g})\end{array}$ & $\begin{array}{c}\text { Shoot height } \\
\text { (cm) }\end{array}$ \\
\hline \multirow{3}{*}{ Maize } & Control & 6.0 & 36.2 & 3.0 \\
\cline { 2 - 5 } & $15 \mathrm{~min}$ & 5.5 & 35.7 & 5.0 \\
\cline { 2 - 5 } & $30 \mathrm{~min}$ & 5.5 & 12.2 & 10 \\
\hline \multirow{3}{*}{ Bean } & Control & 3.0 & 17.2 & 5.5 \\
\cline { 2 - 5 } & $15 \mathrm{~min}$ & 2.5 & 14.0 & 7.0 \\
\cline { 2 - 5 } & $30 \mathrm{~min}$ & 2.5 & 13.3 & 9.0 \\
\hline
\end{tabular}

The seeds of maize and bean were infected with Bacillus sp after exposure to MF for 15 and $30 \mathrm{~min}$. The treated and untreated seeds with MF were germinated on MS medium. The results showed that the plantlets of treated seeds did not infect by Bacillus sp, while the plantlets of untreated seeds were infected with Bacillus sp (Table 2). These results indicated that MF can produce plants free of Bacillus sp. Moore (1979) reported that growth of microorganisms could be stimulated or inhibited depending upon the field strength and frequency of the pulsed magnetic field. Novak et al. (2007) found that the MF decreases the number of yeasts, and also down their growth, which it seems that the MF kills a part of yeasts. They reported that this result was similar to the experiments with bacteria E. coli, S. aureus and L. adecarboxylata.

Table (2): Effect of MF on seeds of maize and bean infected with Bucillus sp.

\begin{tabular}{|c|c|c|}
\hline Seeds & MF/time & Bucillus sp growth \\
\hline \multirow{3}{*}{ Maize } & Control & ++ \\
\cline { 2 - 3 } & $15 \mathrm{~min}$ & - \\
\cline { 2 - 3 } & $30 \mathrm{~min}$ & - \\
\hline \multirow{3}{*}{ Bean } & Control & ++ \\
\cline { 2 - 3 } & $15 \mathrm{~min}$ & - \\
\cline { 2 - 3 } & $30 \mathrm{~min}$ & - \\
\hline
\end{tabular}

\section{Protein and amino acid contents}

Total protein quantity was estimated in seedlings of maize and bean before and after exposure to MF for 15 and $30 \mathrm{~min}$ (Table 3). The total proteins of maize and bean seedlings after treatments were lower than that in control for both times of exposure $(15$ and $30 \mathrm{~min})$. The decrease in total protein of bean was more after treatment for 30 min than 15 min.

Table (3): Percentage of total proteins in seeds of maize and bean.

\begin{tabular}{|c|c|c|}
\hline Seeds & MF/time & Total protein (\%) \\
\hline \multirow{3}{*}{ Maize } & Control & 5.7 \\
\cline { 2 - 3 } & $15 \mathrm{~min}$ & 4.7 \\
\cline { 2 - 3 } & $30 \mathrm{~min}$ & 4.5 \\
\hline \multirow{3}{*}{ Bean } & Control & 12.1 \\
\cline { 2 - 3 } & $15 \mathrm{~min}$ & 11.9 \\
\cline { 2 - 3 } & $30 \mathrm{~min}$ & 4.1 \\
\hline
\end{tabular}

10810 
The amino acids determination showed increase in the amino acids of aspartic, glutamic, and methionine in both maize and bean seeds after treatments with MF for 15 and 30 min as shown in Table (4), while the amino acids of proline, serin and leucin did not affect by the MF.

Table (4): Determination of amino acids in seeds of maize and bean after exposure to magnetic field.

\begin{tabular}{|l|l|c|c|c|c|c|c|}
\hline Seeds & MF/time & \multicolumn{7}{|c|}{ Amino acids } \\
\cline { 3 - 8 } & & $\begin{array}{c}\text { Aspartic } \\
\text { acid }\end{array}$ & $\begin{array}{c}\text { Glutamic } \\
\text { acid }\end{array}$ & Methionine & Proline & Serin & Leucin \\
\hline \multirow{3}{*}{ Maize } & Control & + & + & + & + & + & + \\
\cline { 2 - 8 } & $15 \mathrm{~min}$ & +++ & +++ & +++ & + & + & + \\
\cline { 2 - 8 } & $30 \mathrm{~min}$ & +++ & +++ & +++ & + & + & + \\
\hline \multirow{3}{*}{ Bean } & Control & + & + & + & + & + & + \\
\cline { 2 - 8 } & $15 \mathrm{~min}$ & +++ & +++ & +++ & + & + & + \\
\cline { 2 - 8 } & $30 \mathrm{~min}$ & +++ & +++ & +++ & + & + & + \\
\hline
\end{tabular}

\section{Electrophoretic patterns}

The electrophoretic patterns of seed water-soluble proteins of two varieties of maize and bean without and after treatments with MF for 15 and 30 min are shown in Figure (2) and Table (5).

$$
\text { Maize Bean }
$$

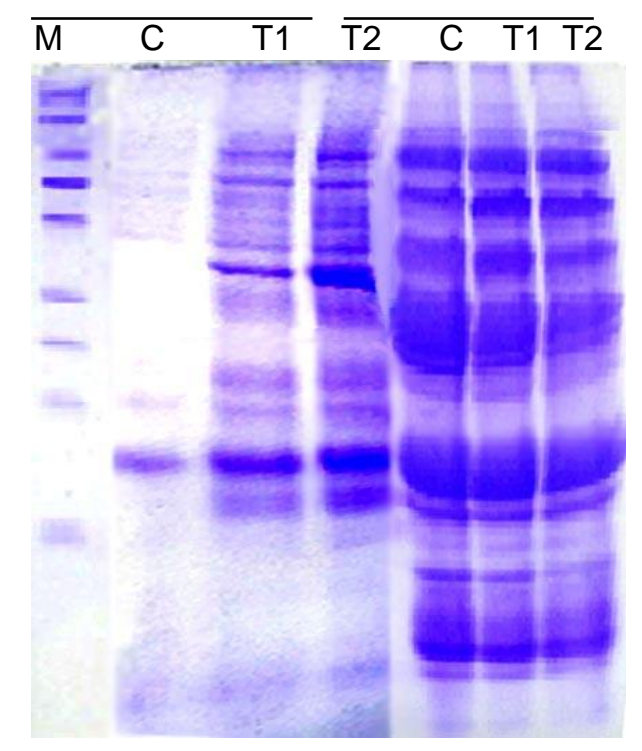

Fig. 2: Electrophoretic patterns of water-soluble proteins for maize variety "S.C. 10" and bean variety "Nebrasca" (C: control, T1 and T2: treatmrnts with MF for $\mathbf{1 5}$ and $\mathbf{3 0} \mathrm{min}$, respectively). M: protein markers $(212,120,97.4,66.2,45,31,20,14.4$ and 6.5 $\mathrm{kDa})$. 
Haggran, A.A. et al.

The protein patterns after treatments with MF showed differences comparing with the control in band numbers and loci. Some bands appeared in the patterns after treatments especially in maize variety where the control showed 11 bands while the treatments gave 16 bands after both 15 and 30 min. On the other hand, in the protein patterns of bean some bands disappeared after treatments especially for $30 \mathrm{~min}$.

Table (5): Densitometric analysis of water-soluble protein bands for two varieties of maize and bean with three treatments of MF, representing band number and molecular weight (MW).

\begin{tabular}{|c|c|c|c|c|c|c|c|}
\hline \multirow{2}{*}{ Band No } & \multirow{2}{*}{ MW (kDa) } & \multicolumn{3}{|c|}{ Maize variety } & \multicolumn{3}{|c|}{ Bean variety } \\
\hline & & $\mathbf{C}$ & T1 & T2 & C & T1 & T2 \\
\hline 1 & 107.2 & - & - & - & + & + & + \\
\hline 2 & 102.7 & - & + & + & + & - & - \\
\hline 3 & 97.4 & + & + & + & - & - & - \\
\hline 4 & 90.7 & - & - & - & + & + & + \\
\hline 5 & 87.4 & - & + & + & - & - & - \\
\hline 6 & 67.5 & + & + & + & - & - & - \\
\hline 7 & 59.8 & - & - & - & + & + & + \\
\hline 8 & 57.0 & + & + & + & - & - & - \\
\hline 9 & 48.3 & - & - & - & + & + & + \\
\hline 10 & 44.5 & + & + & + & - & - & - \\
\hline 11 & 42.1 & + & + & + & - & - & - \\
\hline 12 & 38.9 & + & + & + & - & + & + \\
\hline 13 & 36.7 & - & + & + & - & - & - \\
\hline 14 & 35.8 & - & - & - & + & + & + \\
\hline 15 & 34.3 & - & - & - & + & + & + \\
\hline 16 & 32.6 & - & - & - & + & + & + \\
\hline 17 & 30.5 & + & + & + & - & - & - \\
\hline 18 & 25.5 & - & - & - & + & + & + \\
\hline 19 & 18.6 & - & - & - & + & + & + \\
\hline 20 & 15.6 & + & + & + & + & + & - \\
\hline 21 & 14.4 & + & + & + & + & + & - \\
\hline 22 & 12.7 & - & - & - & + & + & + \\
\hline 23 & 11.8 & + & + & + & - & - & - \\
\hline 24 & 10.0 & - & - & - & + & + & + \\
\hline 25 & 8.8 & - & + & + & + & + & + \\
\hline 26 & 6.7 & - & + & + & + & + & + \\
\hline 27 & 4.5 & - & - & - & + & + & + \\
\hline 28 & 3.6 & - & - & - & + & + & - \\
\hline 29 & 3.0 & - & - & - & + & + & + \\
\hline 30 & 2.6 & + & + & + & + & + & + \\
\hline 31 & 1.8 & - & - & - & + & + & + \\
\hline \multicolumn{2}{|c|}{ Total bands } & 11 & 16 & 16 & 21 & 21 & 18 \\
\hline
\end{tabular}

T1: Treatment for $15 \mathrm{~min}$

T2: Treatment for $\mathbf{3 0} \mathrm{min}$

In maize, five bands with molecular weights (M.W.) of 102.7, 87.4, 36.7, 8.8 and $6.7 \mathrm{kDa}$ were found in the protein band patterns of both treatments for 15 and $30 \mathrm{~min}$. In bean grains, three bands disappeared after 
treatment for 30 min with MW 15.6, 14.4 and $3.6 \mathrm{kDa}$, while one band with MW $102.7 \mathrm{kDa}$ disappeared after treatments for 15 and 30 min. Only one band with MW $38.9 \mathrm{kDa}$ was detected in the lanes of bean protein patterns after treatments, where did not found in the control. The number of bands in the pattern of treatment for 30 min was 18 bands which decreased 3 bands comparing with the control ( 21 bands).

These results indicated that maize can resist the MF stress which produced five new protein bands to overcome this stress. Meanwhile, bean proteins did not affect seriously after treatment for $15 \mathrm{~min}$, but were affected after exposure for $30 \mathrm{~min}$ where four protein bands disappeared. These results coincided with those of protein quantity in bean where the quantity decreased after treatment for $30 \mathrm{~min}$ much more than that after treatment for 15 min (Table 3).

\section{REFERENCES}

Bollage, D.M. and S.J. Eldelstein (1992). Protein extraction. In: Protein Methods. M. Bollag and S. Edelstein ed. Wiley-Liss Inc., New York pp. 27-42.

Brandford, M.M. (1976). A rapid and sensitive for the quantification of microgram quantities of protein utilizing the principle of protein dye binding. Annals of Biochem., 72: 248-254.

Cassidy, H.G. (1957). "Fundamentals of Chromatography", 10, "Technique of Organic Chemistry", edit by Weissberger, A. (Interscience Pub., New York).

Chen, C.J. (1999). Effect of magnetic field on biological cells and applications. Invited session, 14 March, Washington State Convention Center.

Hussien, K.R.F. and H. Stegemann (1978). Comparison of proteins from wheat kernels by various electrophoresis methods in polyacrylamide. $\mathrm{J}$. Agro. and Crop Sci., 14: 668-78.

Goodman, E.M., B. Greenebau and H.T. Marron (1995). Effects of electromagnetic fields on molecules and cells. International Review of Cytology 158: 279-338.

Laemmli, U.K. (1970). Cleavage of structural proteins during the assembly of head of bacteriophage T4. Nature 227: 680-685.

Matsude, T., H. Asou, M. Kobayashi and M. Yonekura (1993). Influences of magnetic fields on growth and fruit production of strawberry. Acta Hortculturae 348: 378-380.

Mulchinger, A.E., J. Boppenmaier, B.S. Dhillon, W.G. Pollmer and R.G. Herrmann (1992). Genetic diversity for RFLPs in European maize inbreds. II. Relation to performance of hybrids within versus between heterotic groups for forage traits. Theor. Appl. Genet., 84: 672-681.

Moore, R.L. (1979). Biological effects of magnetic fields: studies with microorganisms. Can. J. Microbiol., 10: 1145-1151.

Murashige, T. and F. Skoog (1962). A revised medium for rapid growth and bioassays with tobacco tissue cultures. Physiol. Plant. 15: 473-497. 
Haggran, A.A. et al.

Namba, K., A. Sasao and S. Shibusawa (1995). Effect of magnetic field on germination and plant growth. ISHS Acta Horticulture, 399:143-145.

Novak, J., L. Strasak, L. Fojt, I. Slaninova and V. Vetterl (2007). Effect of lowfrequency magnetic field on the viability of yeast Saccharomyces cerevisiae. Bioelectrochemistry 70: 115-121.

Novikov, V.V., I.M. Sheiman and E.E. Fesenko (2002). Effect of weak and extraweak magnetic fields on the intensity of asexual propagation of Planarians Dugesia tigrina, Biofizika 47: 125-129.

Schreiber, W.G., E.M. Teichmann, I. Schiffer, J. Hast, W. Akbari, H. Georgi, R. Graf, M. Hehn, H.W. Spiess, M.Thelen, F. Oesch and J.G. Hengstier (2001). Lack of mutagenic and co-mutagenic effects of magnetic fields during magnetic resonance imaging. J. of Magnetic Resonance Imaging 14: 779-788.

Stegemann, H., A.E.T. Shehata and M. Hamza (1980). Broad bean (Vicia faba L.). Electrophortic studies on seeds of some German and Egyptian cultivars. J. Agronomy and Crop Sci., 149: 447-453.

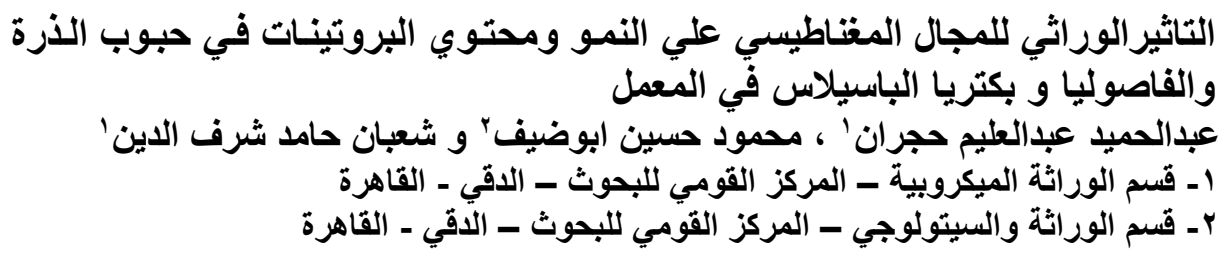

كلية الزراعة - جامعة المنصورة

مركز البحوث الزراعية

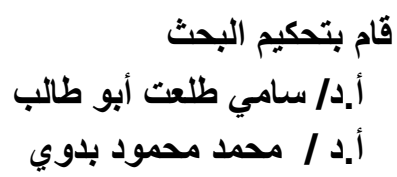

قام بتحكيم البحث

أ.د / محمد محمود بدوي لدوب طالب 
J. Agric. Sci. Mansoura Univ., 34 (12), December, 2009

10815 